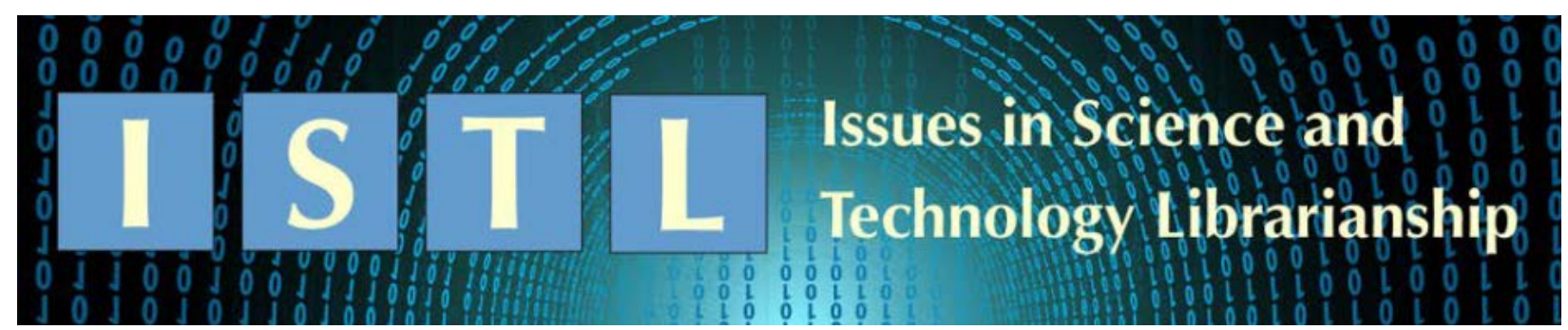

ACRL/STS Section Continuing Education Survey 2018

\title{
STS Professional Development Committee
}

\section{Background}

The ACRL Science and Technology Section (STS) Professional Development Committee conducted a survey in the spring of 2018 to identify the continuing education interests and needs of its membership. In spring 2018, the survey was distributed through the discussion list of the Science and Technology Section of ACRL, STS-L.

The survey was designed and prepared by the members of the STS Professional Development Committee. Amy Jiang administered the survey and compiled the results. This report was prepared by Alyssa Valcourt. Questions about this survey may be directed to Abbie Basile, abasile@odu.edu or Chapel Cowden, chapel-cowden@utc.edu. The results of the survey with an executive summary are presented below.

\section{Executive summary}

The survey was distributed from mid-April 2018 to May 11, 2018. A total of 115 responses were received which was slightly less than the 137 responses received for a similar survey that was undertaken by the STS Professional Development Committee in 2015.

A vast majority of the 2018 survey respondents (97\%) were academic librarians. 47\% of respondents indicated over 10 years of work experience. There was an $8 \%$ decline in response rate from this population since 2015 (55\%). The lowest response rate was from those with 3-5 years of work experience (13\%) which aligns with the $14 \%$ response from librarians with less than three years of experience in 2015. There has been a slight rise in response from librarians with less than three years of experience (19\%). Although $41 \%$ of the respondents indicated having an undergraduate science degree, 55\% librarians showed that they have gained experience as science librarians by working in academic libraries.

In perhaps our most significant and immediately applicable findings, most librarians surveyed (78\%) showed a preference towards receiving continuing education via webinars and teleconferences, closely followed by a preference towards receiving continuing education at conferences or preconference workshops (74\%). Other suggested preferences included self-paced learning modules, science boot camps, and departmental seminars. Only $19 \%$ of respondents were interested in taking credit courses. When asked what types of credit coursed would be preferred, librarians voted for distance education (46\%), MOOC (36\%), and post-MLS/MLIS certification program (32\%). 
The survey presented a list of 36 pre-selected topics with the intent of gauging potential interest of science librarians for professional development activities. Survey participants were asked to rate interest on a scale of 1 to 5, 1 being "least interested" to 5 being "most interested." Five topics ranked at the top of the survey. The first one was "Data Literacy Instruction" with a score of 3.97. The second one was "Library Instruction" with a score of 3.96. The third top ranked topic was "Evaluating existing services/developing new services" with a score of 3.93. The fourth was "Consultation and collaboration with faculty and students" with a score of 3.9. The fifth was "Data manipulation and analysis" with a score of 3.83. Looking at topics science librarians were most interested in for professional development, the highest rated topics could be separated into three categories- data literacy, research and publishing tools, and new and current library services. "Managing Approval Plans" and "Working with Consortia" received the lowest scores. This is not surprising considering that Acquisitions and E-resources librarians at many institutions undertake most of these roles.

Other ranked topics in which respondents showed interest included specific subject areas, marketing, data visualization, developing a research agenda, budgeting, and impact factors, citation metrics, and altmetrics. While pre-selected topics were available, the survey did ask if any other topics could be of possible interests to science librarians for professional development activities. One group of responses focused upon scarcity of resources and/or space and staff consolidation, particularly as it relates to STEM librarianship. Another group of responses had a strong focus on the research process including access to data, research in progress resources, and new publishing models.

\section{Recommendations for future continuing education programs}

The drop in participant responses to this survey and consistent low response rate from science librarians who have been in the field less than five years suggests steps are needed to raise awareness of STS and have more of a presence in offering or highlighting professional development for science librarians.

There is a great interest among science librarians to use free resources to obtain professional development in the areas of interest. Preferred modes of learning include webinars, virtual preconferences, or self-paced learning modules. Professional development topics of interest include science-specific library instruction in the classroom/lab, data literacy, teaching the research process from start to publication, and new and current library services.

By providing webinars, the STS Professional Development Committee could become more visible, create partnerships with other organizations, and provide free professional development at a time where library budgets are struggling. 


\section{Detailed Results}

\section{Q.1 Where do you work?}

\begin{tabular}{|l|l|l|}
\hline \multicolumn{1}{|c|}{ Answer Options } & Response & Percentage \\
\hline Academic library & 112 & $97.4 \%$ \\
\hline Corporate library & 0 & $0 \%$ \\
\hline Government library & 2 & $1.7 \%$ \\
\hline Public library & 0 & $0 \%$ \\
\hline Other type of library or library organization & 0 & $0 \%$ \\
\hline Do not work in a library & 1 & $.9 \%$ \\
\hline \multicolumn{1}{|c|}{ Total } & $\mathbf{1 1 5}$ & $\mathbf{1 0 0 \%}$ \\
\hline
\end{tabular}

\section{Q.2 How many years since receiving Master's degree in library science?}

\begin{tabular}{|l|l|l|}
\hline Answer Options & Response & Percentage \\
\hline Less than 3 years & 22 & $19.1 \%$ \\
\hline 3-5 years & 15 & $13 \%$ \\
\hline 6-10 years & 24 & $20.9 \%$ \\
\hline More than 10 years & 54 & $47 \%$ \\
\hline Degree in progress & 0 & $0 \%$ \\
\hline Total & $\mathbf{1 1 5}$ & $\mathbf{1 0 0} \%$ \\
\hline
\end{tabular}

Q.3 What is your background in the Sciences, Applied Sciences, or Engineering? (Mark all that apply)

\begin{tabular}{|c|c|c|}
\hline Answer Options & Response & Percentage \\
\hline No educational background & 17 & $14.8 \%$ \\
\hline Some undergraduate study & 22 & $19.1 \%$ \\
\hline Undergraduate degree & 47 & $40.9 \%$ \\
\hline Some graduate study & 12 & $10.4 \%$ \\
\hline Master’s Degree & 27 & $23.5 \%$ \\
\hline PhD & 6 & $5.2 \%$ \\
\hline Continuing education & 14 & $12.2 \%$ \\
\hline Library work experience & 63 & $55 \%$ \\
\hline Non-librarian work experience & 26 & $22.6 \%$ \\
\hline Others (please specify) & 4 & $3.5 \%$ \\
\hline Total & 405 & $100 \%$ \\
\hline
\end{tabular}


Q.4 How would you prefer to receive continuing education? (Mark all that apply)

\begin{tabular}{|c|c|c|}
\hline Answer Options & Response & Percentage \\
\hline Credit course & 22 & $19.1 \%$ \\
\hline Conference or pre-conference workshop & 85 & $73.9 \%$ \\
\hline Other workshops & 15 & $13 \%$ \\
\hline Consulting with mentor & 31 & $27 \%$ \\
\hline Webinars or teleconferences & 90 & $78.3 \%$ \\
\hline Web-based information & 67 & $58.3 \%$ \\
\hline Other (please specify) & 8 & $7 \%$ \\
\hline \multicolumn{3}{|c|}{$\begin{array}{l}\text { Other (please specify): } \\
\text { Something that comes with practice, hands-on, exercises, etc. } \\
\text { Experiences } \\
\text { Years ago they had these things called books. } \\
\text { Self-Paced Learning Modules, online synchronous or asynchronous workshops/hands on style webinars } \\
\text { Free or low-cost virtual webinars/courses } \\
\text { Departmental seminar } \\
\text { Science boot camps } \\
\text { Working with colleagues; updates, as from STS lists; ALA sessions }\end{array}$} \\
\hline
\end{tabular}

Q.5 What types of credit courses would you consider taking to further your education? (Mark all that apply)

\begin{tabular}{|l|l|l|}
\hline \multicolumn{1}{|c|}{ Answer Options } & Response & Percentage \\
\hline Classroom-based course & 30 & $26.1 \%$ \\
\hline Distance education & 53 & $46.1 \%$ \\
\hline MOOC & 41 & $35.7 \%$ \\
\hline Within an ALA approved MLS/MLIS program & 15 & $13 \%$ \\
\hline Within a post-MLS/MLIS certification program & 37 & $32.2 \%$ \\
\hline Undergraduate or Continuing Education course in assigned subject areas & 28 & $24.3 \%$ \\
\hline Undergraduate or Continuing Education technology skills course & 19 & $16.5 \%$ \\
\hline Not interested in credit coursework & 38 & $33 \%$ \\
\hline \multicolumn{1}{|c|}{ Total } & $\mathbf{2 6 1}$ & $\mathbf{1 0 0 \%}$ \\
\hline
\end{tabular}


Q.6 On a scale of 1-5 with 1 being "least interested" and 5 being "very interested," please indicate how interested you are in learning more about the following continuing education topics.

\begin{tabular}{|c|c|c|c|c|c|c|}
\hline Answer Options & 1 & 2 & 3 & 4 & 5 & $\begin{array}{l}\text { Rating } \\
\text { Average }\end{array}$ \\
\hline Data literacy instruction & 5 & 8 & 20 & 35 & 47 & 3.97 \\
\hline Library instruction & 5 & 7 & 20 & 39 & 44 & 3.96 \\
\hline Evaluating existing services/developing new services & 6 & 4 & 24 & 39 & 42 & 3.93 \\
\hline Consultation and collaboration with faculty and students & 4 & 5 & 25 & 45 & 36 & 3.9 \\
\hline Data manipulation and analysis & 8 & 7 & 25 & 32 & 43 & 3.83 \\
\hline Specific subject area librarianship & 6 & 7 & 26 & 39 & 37 & 3.82 \\
\hline Marketing library resources and services & 4 & 9 & 28 & 38 & 36 & 3.81 \\
\hline Data visualization (labs, services, etc.) & 5 & 14 & 20 & 37 & 39 & 3.79 \\
\hline Research data management & 7 & 10 & 29 & 27 & 42 & 3.76 \\
\hline Impact factors, citation metrics, altmetrics & 5 & 10 & 26 & 41 & 33 & 3.76 \\
\hline Developing a research agenda & 9 & 8 & 29 & 35 & 34 & 3.67 \\
\hline Embedded library services & 8 & 10 & 27 & 42 & 28 & 3.63 \\
\hline Open access publishing models & 7 & 10 & 33 & 40 & 25 & 3.57 \\
\hline Grant writing & 5 & 16 & 33 & 36 & 25 & 3.52 \\
\hline Diversity and Inclusivity & 13 & 13 & 24 & 36 & 29 & 3.48 \\
\hline Managing and utilizing usage statistics & 11 & 15 & 29 & 33 & 27 & 3.43 \\
\hline Copyright issues & 9 & 13 & 36 & 40 & 17 & 3.37 \\
\hline Collection development in specific subject areas & 12 & 17 & 30 & 34 & 22 & 3.32 \\
\hline Professional advancement & 8 & 16 & 36 & 41 & 14 & 3.32 \\
\hline Linked/open data & 17 & 16 & 25 & 27 & 30 & 3.32 \\
\hline Video tutorial applications & 10 & 18 & 38 & 28 & 21 & 3.28 \\
\hline Programming (e.g. in Python, R, etc.) & 13 & 28 & 19 & 26 & 29 & 3.26 \\
\hline $\begin{array}{l}\text { Developing management skills (budgeting, supervision, personnel } \\
\text { recruiting, training, performance evaluation, etc.) }\end{array}$ & 16 & 17 & 32 & 35 & 15 & 3.14 \\
\hline Patent and trademark sources, searching, etc. & 15 & 16 & 35 & 38 & 11 & 3.12 \\
\hline Institutional repositories & 14 & 22 & 38 & 28 & 13 & 3.03 \\
\hline LibGuides & 16 & 24 & 37 & 22 & 16 & 2.98 \\
\hline Web page design & 20 & 25 & 34 & 21 & 15 & 2.88 \\
\hline Discovery services & 15 & 25 & 43 & 27 & 5 & 2.84 \\
\hline Mobile apps & 19 & 28 & 36 & 24 & 8 & 2.77 \\
\hline
\end{tabular}




\begin{tabular}{|l|l|l|l|l|l|l|}
\hline $\begin{array}{l}\text { Managing electronic journals: purchasing, subscribing, } \\
\text { platform/license issues }\end{array}$ & 27 & 30 & 25 & 16 & 17 & 2.7 \\
\hline Makerspaces & 24 & 29 & 38 & 12 & 12 & 2.64 \\
\hline Managing archival rights & 20 & 37 & 35 & 13 & 10 & 2.62 \\
\hline Managing e-Books: purchasing, subscribing, platform/license issues & 34 & 26 & 24 & 15 & 16 & 2.59 \\
\hline Patron-driven acquisition & 30 & 28 & 25 & 27 & 5 & 2.56 \\
\hline Working with consortia & 34 & 20 & 34 & 20 & 7 & 2.53 \\
\hline Approval Plans & 38 & 31 & 32 & 13 & 1 & 2.2 \\
\hline
\end{tabular}

\section{Q.7 Are there topics not listed in the previous question that you would like to learn about? Please list them here.}

Total responses received were 20. The topics suggested were as follows that are grouped under broad headings:

Leadership/Administration

- community outreach- how to use UX and understand user needs when there are limited resources

- fundraising and development for Science and Engineering collections

- staff shortages- make embedded librarians unfeasible since there are not enough people to offer the service to all programs

- succession planning

- supervision of student employees

- surviving library restructuring, specifically as branches or departments get folded into units without a STEM focus

Specific Subject Area Librarianship/STEM Librarianship

- access to and using patent databases

- government documents management

- helpful software/learning commons services to connect physical space on new ways to patrons

- integrating information literacy into instruction in the sciences/data classes

- science education and resources for non-science majors

- ways to re-enter the field when you've been out for a few years

- weeding for science and engineering materials

Research/Scholarly Publishing

- access to corresponding data

- copyright, rights management

- data literacy

- dataset citations

- new publishing models

- research in progress resources

- research methods and research design 